\title{
Processing and characterization of extruded breakfast meal formulated with broken rice and bean flour
}

\author{
Processamento e caracterização de refeição matinal extrusada formulada com farinha de grãos \\ quebrados de arroz e feijão
}

\author{
Ana Vânia CARVALHO ${ }^{1}$, Rafaella de Andrade MATTIETTO $^{1}$, Priscila Zaczuk BASSINELLO ${ }^{2 *}$, \\ Selma Nakamoto KOAKUZU² ${ }^{2}$ Alessandro de Oliveira RIOS ${ }^{3}$, Renan de Almeida MACIEL ${ }^{4}$, \\ Rosangela Nunes CARVALHO²
}

\begin{abstract}
The objective of this work was to develop an extruded breakfast product containing broken rice and split old beans and to verify the influence of the extrusion process on their physicochemical, technological, and sensory characteristic. The final product had a protein content of $9.9 \mathrm{~g} .100 \mathrm{~g} \mathrm{~g}^{-1}$, and therefore it can be considered a good source of proteins for children and teenagers. The dietary fiber content of the final edible product was $3.71 \mathrm{~g} .100 \mathrm{~g}^{-1}$. Therefore, the breakfast meal may be considered as a source of dietary fiber according to Brazilian law . As for the technological properties, the extruded product presented an expansion index of 8.89 and apparent density of $0.25 \mathrm{~g} . \mathrm{cm}^{-3}$. With regard to the sensory analysis, the acceptance average was ranked between 6.8 and 7.7, corresponding to the categories "liked slightly" and "liked very much". With regard to purchase intention, $79 \%$ of the panelists said they would certainly or possibly purchase the product. Broken rice and split old beans are interesting alternatives for the elaboration of extruded breakfast products presenting good nutritional, technological, and sensory qualities.

Keywords: Phaseolus vulgaris; Oryza sativa L.; thermoplastic extrusion; technological properties; nutritional characteristics; sensory acceptability.
\end{abstract}

\section{Resumo}

O objetivo deste trabalho foi elaborar um produto matinal extrusado de quirera de arroz e bandinha de feijão, além de verificar a influência do processo de extrusão nas suas características físico-químicas, nutricionais, tecnológicas e sensoriais. O produto final apresentou teor considerável de proteínas $\left(9,9 \mathrm{~g} .100 \mathrm{~g}^{-1}\right)$, podendo ser considerado uma boa fonte desse nutriente para crianças e adolescentes. Para a fibra alimentar, observou-se teor de $3,71 \mathrm{~g} .100 \mathrm{~g}^{-1}$ do produto pronto para o consumo. Dessa forma, o floco matinal de arroz e feijão pode receber a alegação de alimento fonte de fibras, de acordo com a legislação brasileira. Com relação às propriedades tecnológicas, o extrusado estudado apresentou índice de expansão de 8,89 e densidade aparente de $0,25 \mathrm{~g} \cdot \mathrm{cm}^{-3}$. Quanto à análise sensorial, o floco matinal avaliado obteve notas médias de aceitação, situadas no intervalo de 6,8 a 7,7, que corresponde às categorias "gostei ligeiramente" e "gostei muito". Para a intenção de compra, $79 \%$ dos provadores opinaram que certamente ou possivelmente comprariam o produto. O emprego de quirera de arroz e bandinha de feijão é uma interessante alternativa para a elaboração de produto matinal extrusado, apresentando boas qualidades de ordem nutricional, tecnológica e sensorial.

Palavras-chave: Phaseolus vulgaris; Oryza sativa; extrusão termoplástica; propriedades tecnológicas; características nutricionais; aceitabilidade sensorial.

\section{Introduction}

The consumption of breakfast cereals or related products has increased recently, mainly due to the lack of time for food preparation in modern times (TAKEUCHI; CUNHA; SABDINI, 2005). The Nielsen Company (2012) reported that in 2008 only $17.7 \%$ of Brazilian population consumed this kind of product at home, which represents a good opportunity of increasing the breakfast cereal and flakes category in the market. Based on an IBGE survey (INSTITUTO..., 2010a), there has been a decline in the household consumption of traditional items such as beans (from $6.6 \%$ to $5.4 \%$ ) and rice (from $17.4 \%$ to $16.2 \%$ ), while the consumption of industrialized foods, such as breads (from $5.7 \%$ to $6.4 \%$ ), biscuits (from $3.1 \%$ to $3.4 \%$ ), ready-to-eat meals (from $3.3 \%$ to $4.6 \%$ ), and others, have increased. Breakfast cereals and flakes are extruded products traditionally eaten with milk, and starch is its main component (MENEZES; SOUZA, 2006). They may be considered source of proteins, but are incomplete due

${ }^{1}$ Food Processing Laboratory, Embrapa Eastern Amazon Research Center - CPATU, Trav. Dr. Enéas Pinheiro s/n, CEP 66095-100, Belém, PA, Brazil

2 Embrapa Rice and Beans Research Center-CNPAF, Rod. GO-462, Km 12, Zona rural, CP 179, CEP 75375-000, Santo Antônio de Goiás, GO, Brazil, e-mail:priscilazb@cnpaf.embrapa.br

${ }^{3}$ Food Science and Technology Institute, Federal University of Rio Grande do Sul - UFRGS, Av. Bento Gonçalves, 9500, Prédio 43212, CEP 91501-970, Porto Alegre, RS, Brazil

${ }^{4}$ Federal University of Pará - UFPA, Rua Augusto Corrêa, 01, Guamá, CEP 66075-110, Belém, PA, Brazil

${ }^{*}$ Corresponding author 
to the limiting effect of certain essential amino acids, such as lysine (JONES, 2001).

To increase the protein content and improve the nutritive value of extruded products, various sources of protein, such as corn, oats, soybeans, rice, beans, and other products may be added to their formulation (TEBA; ASCHERI; CARVALHO, 2009; SILVA et al., 2011; BASSINELLO et al., 2011). The enrichment of this kind of food is of great interest for consumers; especially those looking for a daily ingestion of more nutritive products with adequate contents of nutrients for children and teenagers' development and for keeping adults healthy as well (MENEZES; SOUZA, 2006).

Rice (Oryza sativa L.) is one of the most grown crop in the world, and it is the staple food for more than half of the world's population. It is an excellent source of energy with high starch concentration besides proteins, vitamins, and minerals (WALTER; MARCHEZAN; ÁVILA, 2008). Rice has a limiting concentration of lysine, an essential amino acid, but compared to other cereals, its higher concentration of lysine contributes for a more complete amino acids balance (JULIANO, 1993).

During processing, $14 \%$ of the rice comes out as broken grains, commercially classified as a low value product although having the same proximal composition of the unbroken grain (SILVA; ASCHERI, 2009). A large portion of this by-product is transformed into rice flour used as raw material in the elaboration of different types of foods through the extrusion process (DORS; CASTIGLIONI; RUIZ, 2006; CLERICI; EL-DASH, 2008).

In Brazil, common beans (Phaseolus vulgaris L.) are the main source of proteins and have long been considered the staple food of low-income populations (FERREIRA; DEL PELOSO; FARIA, 2002; MECHI; BRAZACA; ARTHUR, 2005). A study regarding Brazilian nutritional household evaluation by IBGE (INSTITUTO..., 2010b) has identified some changes in dietary pattern, such as high sugar intake (16.36\%), insufficient participation of fruit (2.04\%), vegetables and legumes $(0.80 \%)$, and a high participation of protein from animal source. All essential amino acids are present in the common beans. They are rich in lysine, present in small amounts in rice, but limited in sulfur amino acids methionine and cysteine; therefore their combination with cereals such as rice is necessary to attain an adequate diet regarding amino acids (FONSECA MARQUES; BORA, 2000; PIRES et al., 2006).

Thermoplastic extrusion has been gaining momentum and has expanded in the food industry because it is an important technique that increases the availability of processed food, besides providing advantages when compared to other processing systems such as versatility, relatively low cost, high productivity, environmentally-friendly and safe (GUY, 2001). Additionally, it favors the degradation of thermo sensitive anti nutrients, mainly those present in beans, microorganisms' elimination, protein denaturation, and the higher nutrients digestibility due to food matrix rupture (ROCHA-GUZMAN et al., 2008).

The extrusion process for breakfast flakes includes ingredients that under the action of heat, moisture, pressure, and shear are transformed into a viscoelastic mass. The sudden drop in pressure allows water to evaporate with subsequent expansion of the product mass (STRAHM, 1998; TAKEUCHI; CUNHA; SABDINI, 2005)

The objective of this study was to elaborate a breakfast cereal type product or flakes with broken rice and split beans to evaluate the effect of the proposed formulation on the physicochemical and technological characteristics and on the amino acid profile and to evaluate the acceptability of the final product.

\section{Materials and methods}

\subsection{Flour production}

Broken rice and split old bean grains ('carioca' type) were obtained from local rice and bean processing and packaging industries (Cristal Alimentos and Feijão Barão companies at Goiânia - GO, respectively, in 2008) and sent to Embrapa Eastern Amazon Research Centre. The samples were ground in a Willye type knife mill (TE-650 - Tecnal, Piracicaba, São Paulo, Brazil) to a particles size between 9 and 20 mesh, were conditioned separately in plastic bags, and stored at room temperature for further processing.

\subsection{Granulometric characterization}

The granulometric characterization for both flours was performed using a Produtest vibrator and sieves of meshes $9,20,28$, and 35 . The time was set at ten minutes, and the intensity of vibration was set on position 8 in the rheostat (CARVALHO et al., 2010).

\subsection{Flakes processing}

The product formulation was prepared by mixing $30 \%$ of bean flour, $70 \%$ of rice flour, and $5 \%$ of sugar. These proportions were preliminary optimized according to the applied central composite rotation experimental design in order to define the most satisfactory formulation. The moisture content was adjusted to $14 \%$ by adding the quantity of water calculated in accordance with the following equation: $\mathrm{Y}=\left(\mathrm{U}_{\mathrm{f}}-\mathrm{U}_{\mathrm{i}}\right) \times \mathrm{P}_{\mathrm{s}} / 100-\mathrm{U}_{\mathrm{f}}$, where $\mathrm{Y}=$ water quantity to be added $(\mathrm{mL}) ; \mathrm{U}_{\mathrm{f}}=$ final sample moisture; $\mathrm{U}_{\mathrm{i}}=$ initial sample moisture; and $\mathrm{P}_{\mathrm{s}}=$ sample weight $(\mathrm{g})$. The samples were processed in a single screw extruder (Labor PQ30INBRAMAQ, Indústria de Máquinas Ltda. Ribeirão Preto, São Paulo, Brazil) with the following characteristics: interchangeable configurations and screw; control of temperature in the various heating zones, and adjustable screw speed. The following parameters were set for the temperature zones: (Zone $1=40^{\circ} \mathrm{C}$ ); Zone $2=60^{\circ} \mathrm{C}$; zone $3=80^{\circ} \mathrm{C}$ ); screw speed of $277 \mathrm{rpm}$; feeding rate of $292 \mathrm{~g} /$ minutes, and circular matrix of $3.85 \mathrm{~mm}$.

The flake obtained was $2 \mathrm{~cm}$ in length (Figure 1) and was sprayed with a $70{ }^{\circ}$ Brix sucrose solution with a volume corresponding to $35 \%$ of sugar, dried in a forced air oven at $60{ }^{\circ} \mathrm{C}$ for 3 hours, conditioned in plastic bags, and stored at room temperature for further analyses. 


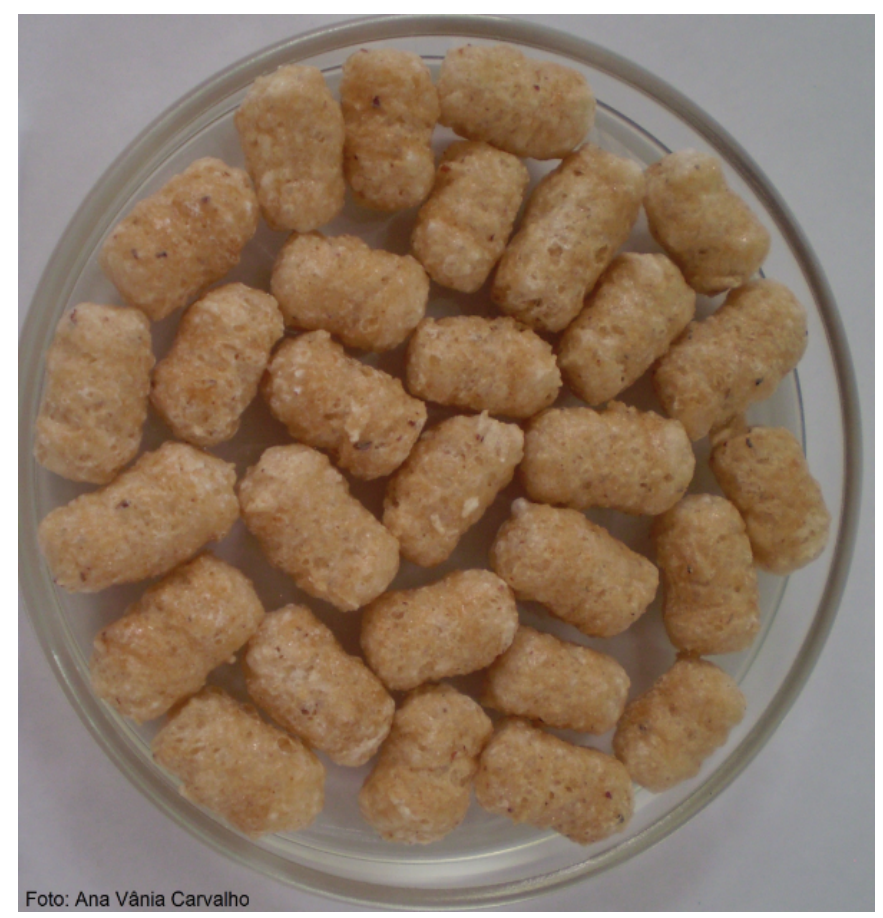

Figure 1. Image of the breakfast meal (final extruded product).

\subsection{Physicochemical characterization of flours and flakes}

Both flours and the extruded final product obtained were characterized for moisture content, ash; proteins; lipids (ASSOCIATION..., 1997); total dietary fiber (enzymatic-gravimetric method No 991.43 from AOAC (ASSOCIATION..., 1997); and carbohydrates (calculated by the difference between 100 and the sum of the percentage of water, proteins, lipids, and ash); total energetic value (UNITED..., 1963); tannins (colorimetric method described by FolinDenis no 952.03, ASSOCIATION..., 1997); phytates (HAUG; LANTZSCH, 1983); and total amino acids (WHITE; HART; KRY, 1986). The following determinations were also performed for the breakfast flake: water activity (direct measurement using a water activity analyzer DECAGON, model Pawkit, Pullman USA); thiamine (vitamin B1) content (EUROPEAN..., 2003a), pre-column derivation by thiochrome according to Presoto and Almeida-Muradian, 2008; and Riboflavin (vitamin B2) (EUROPEAN..., 2003b) by High Performance Liquid Chromatography (HPLC), according to methods standardized by the European Commission for Standardization.

\subsection{Technological characterization of the breakfast flake}

The following analyses were performed to characterize technologically the extruded product: apparent density (ASCHERI; CARVALHO, 1997); radial expansion index (ALVAREZ-MARTINEZ; KONDURY; HARPER, 1988), and instrumental texture using the texture analyzer Stable Micro System (Surrey, England, model TAXT Plus) fitted with $50 \mathrm{~kg}$-load cell and a $2 \mathrm{~mm}$-cylindrical compression accessory. The parameters used in this experiment were: pre-test speed of $0.5 \mathrm{~mm} / \mathrm{s}$, test speed of $0.5 \mathrm{~mm} / \mathrm{s}$, after-test speed of $10 \mathrm{~mm} / \mathrm{s}$, and probe travel distance of $3 \mathrm{~mm}$. The results are averaged over ten replicates and expressed in g.f.

\subsection{Sensory analysis}

Acceptance was evaluated using a 9-point structured hedonic scale ranging from 9 (liked extremely) to 1 (disliked extremely) (STONE; SIDEL, 1993). This analysis was performed at the Laboratory of Sensory Analysis at the Federal University of the State of Pará and at the Laboratory of Food Science of the Embrapa Eastern Amazon by a group of 100 untrained panelists including staff, visitors, and students. Pure samples (without milk or other similar vehicle) were presented to the potential consumers in randomly identified plastic dishes, at room temperature, and were evaluated according to color, flavor, texture, overall impression, and purchase intention (structured 5 point scale: $1=$ certainly would not buy; $5=$ certainly would buy). The percentage of each sensory attribute was calculated taking the score 9 as $100 \%$ of acceptance.

\subsection{Statistical analysis}

All statistical analyses were carried out using the STATISTICA software (STATSOFT, 1995). The data were subjected to analysis of variance (ANOVA) and Tukey test $(\mathrm{p}<0.05)$.

\section{Results and discussion}

\subsection{Raw material particle size}

Particle size affects significantly the cooking process and the final product texture. On one hand, its importance is related to the water diffusivity in the particles, which according to their size may have a higher or lower ability to absorb water during raw material conditioning; and, on the other hand, the difference in size can affect the cooking degree and the homogeneity of the elaborated mass (CARVALHO et al., 2010).

As shown in Table 1, most of the particles were retained on $9-20$ mesh sieves, $61.58 \%$ for rice flour and $84.23 \%$ for the split beans, showing that the raw material had a relatively homogeneous granulometry.

Such homogeneity is very important to obtain satisfactory results in extruded products. If the particles have a significant difference in size, the extruded product may present undesired particles with different cooking degrees thus affecting the quality, appearance, and palatability of the expanded product (MOHAMED, 1990). In addition, small particles may agglomerate when subjected to moisture increase forming lumps during conditioning and larger size particles are harder to condition (RIAZ, 2000).

\subsection{Physicochemical characterizations of the raw material and breakfast flake}

The quality of an extruded product is affected by the physicochemical composition of the raw material, as reported by Carvalho, Ascheri and Cal-Vidal (2002) and González, 
Torres and De Greef (2002). Characteristics such as texture and crunchiness are highly influenced by such composition (ASCHERI et al., 1995).

As shown in Table 2, the carbohydrates are the main components of broken rice $(80.16 \%)$, as reported by Juliano (1993). The results of protein, lipids, fiber, and ash obtained for the broken rice flour are close to those reported by Mendonça, Ascheri and Ascheri (2001), Tedrus et al. (2001), Dors, Castiglioni and Ruiz (2006) and consistent with the Brazilian Table of Food Composition (UNIVERSIDADE..., 2006), which shows protein contents varying from $6.83 \%$ to $9.81 \%$; fibers from $0.17 \%$ to $1.70 \%$; lipids from $0.30 \%$ to $0.89 \%$, fibers from $0.17 \%$ to $1.70 \%$ and ash from $0.2 \%$ to $0.78 \%$. The moisture content of the broken rice set at $11.74 \%$ is close to the values in the Brazilian Table of Food Composition (UNIVERSIDADE..., 2006) and those reported by Limberger et al. (2009), who found moisture contents of $13.2 \%$ and $10.87 \%$.

The split bean flour presented $64.20 \%$ of carbohydrates, high protein content of $20.20 \%$, and $7.02 \%$ of dietary fiber. These results are close to those found by Antunes et al. (1995), Ramírez-Cárdenas, Leonel and Costa (2008) and Silva, Rocha and Canniati Brazaca (2009), who reported protein contents from $22.57 \%$ to $25.77 \%$; carbohydrates from $43.84 \%$ to $77.28 \%$; lipids from $1.25 \%$ to $2.56 \%$; dietary fiber from $3.82 \%$ to $25.08 \%$; and ashes from $3.36 \%$ to $4.95 \%$ in various cultivars and lines of common beans. According to the Brazilian Table of Food Composition (UNIVERSIDADE..., 2006), Carioca type beans presented a proximal composition similar to that found in this study, $14 \%$ of moisture; $61,2 \%$ of carbohydrates; $20.0 \%$ of proteins; $18.4 \%$ of dietary fiber; $3.5 \%$ of ashes; and $1.3 \%$ of lipids.

The results also show that the extrusion and drying processes led to loss of moisture, which was predictable since these processing steps promote loss of water. The same effect was also observed by Limberger et al. (2009) in salted snack chips manufactured with broken rice and by Vernaza, Chang and Steel (2009) in breakfast cereals containing corn flour and soybeans meal, who reported moisture contents of $5.11 \%$ and $3.74 \%$, respectively. Besides the low moisture content, the breakfast flake presented a low water activity of 0.35 . Such low value gives stability to microbial action since according to Labuza (1980) food is stable regarding microorganisms deterioration when the water activity is lower than 0.60 . It was also observed in Table 2 that the carbohydrates were the components present in the largest amount (82.29\%); a characteristic of this kind of product.

Protein content was $9.9 \%$, a value higher than that reported by Limberger et al. (2009), 8.91\%, for extruded broken rice snacks, and those reported by Lanfer Marquez et al. (1997), 3.8\% and $7.3 \%$, in thirteen different flaked cereals. Those differences are probably due to the fact that beans have higher content of proteins than rice. Yet, Vernaza, Chang and Steel (2009) reported $8.55 \%$ of proteins in organic breakfast cereals containing corn meal and passion fruit meal. According to the Brazilian Table of Food Composition (UNIVERSIDADE..., 2006), the average protein content of corn-based breakfast cereals is $7.2 \%$; therefore, the processing of rice and bean-based breakfast cereal results in a final product with higher protein content than those usually available at the market. Also, according to resolution RDC no 269, of September 22 ${ }^{\text {nd }}, 2005$, the split beans and broken rice-based breakfast flake can represent a good source of proteins for adults and children of 7-10 years old meeting the requirement of a minimum of $20 \%$ and $29 \%$, respectively, of the Recommended Daily Intake (RDI) (BRASIL 2003, 2005) for each $100 \mathrm{~g}$ consumed.

Table 1. Granulometric analysis of broken rice and split bean flours*.

\begin{tabular}{|c|c|c|c|c|c|}
\hline \multirow{2}{*}{ Flour } & \multicolumn{5}{|c|}{ Particle size (mesh) } \\
\hline & $>9$ & $9-20$ & $20-28$ & $28-35$ & $<35$ \\
\hline Broken rice (\%) & $0.00 \pm 0.00$ & $61.6 \pm 1.07$ & $37.0 \pm 0.17$ & $0.53 \pm 0.51$ & $0.87 \pm 0.50$ \\
\hline Split beans (\%) & $3.7 \pm 0.32$ & $84.2 \pm 0.55$ & $11.4 \pm 0.32$ & $0.23 \pm 0.06$ & $0.43 \pm 0.23$ \\
\hline
\end{tabular}

${ }^{*}$ Values are means $(\mathrm{n}=3) \pm$ standard deviations and 9 mesh $=2 \mathrm{~mm} ; 20$ mesh $=0.85 \mathrm{~mm} ; 28 \mathrm{mesh}=0.60 \mathrm{~mm} ; 35 \mathrm{mesh}=0.42 \mathrm{~mm}$.

Table 2. Physicochemical characterization of broken rice, split beans, breakfast rice, and bean flakes after drying and sprinkling of sugar ${ }^{\star}$.

\begin{tabular}{|c|c|c|c|}
\hline Determinations & Broken rice & Split beans & Rice and bean flakes \\
\hline Water activity & - & - & $0.4 \pm 0.02$ \\
\hline Moisture content (\%) & $11.7 \pm 0.74$ & $10.8 \pm 0.05$ & $6.7 \pm 0.19$ \\
\hline Proteins (\%) & $7.5 \pm 0.20$ & $20.2 \pm 0.39$ & $9.9 \pm 0.17$ \\
\hline Lipids (\%) & $0.36 \pm 0.01$ & $0.88 \pm 0.03$ & $0.07 \pm 0.01$ \\
\hline Ashes (\%) & $0.24 \pm 0.01$ & $3.8 \pm 0.12$ & $1.0 \pm 0.04$ \\
\hline Total dietary fibre (\%) & $1.1 \pm 0.22$ & $17.0 \pm 0.92$ & $3.7 \pm 0.02$ \\
\hline Total carbohydrates (\%) & $80.2 \pm 0.92$ & $64.3 \pm 0.36$ & $82.3 \pm 0.45$ \\
\hline Energetic value $\left(\mathrm{kcal} .100 \mathrm{~g}^{-1}\right)$ & $353.8 \pm 3.01$ & $345.7 \pm 0.65$ & $354.5 \pm 1.36$ \\
\hline Thiamine (mg.100 g-1) & $0.03 \pm 0.00$ & $0.45 \pm 0.00$ & $0.05 \pm 0.00$ \\
\hline Riboflavin (mg.100 g $\mathrm{g}^{-1}$ ) & $0.03 \pm 0.00$ & $0.15 \pm 0.00$ & $0.04 \pm 0.00$ \\
\hline Tannins (mg.100 $\mathrm{g}^{-1}$ ) & $18.4 \pm 0.63$ & $461.4 \pm 10.86$ & $75.7 \pm 2.36$ \\
\hline Phytates (mg.100 g ${ }^{-1}$ ) & $34.0 \pm 1.03$ & $399.3 \pm 13.26$ & $165.9 \pm 8.99$ \\
\hline
\end{tabular}

${ }^{*}$ Wet basis results $(\mathrm{n}=3)$. Values are means \pm standard deviations. 
According to Pires et al. (2006), for a protein to be classified as high quality or of high biological value, it has to present high digestibility and supply adequate amounts of essential amino acids.

In Table 3, it can be seen that the broken rice met the nutritional requirements for children 1-3 years of age, as established by the Institute of Medicine (2005), for all amino acids, except for lysine and tryptophan. The limiting effect of lysine was reported by Juliano (1993). The amino acid present in the largest amount in the broken rice was glutamic acid: $16.97 \mathrm{mg} .100 \mathrm{mg}^{-1}$ of protein, in accordance with Saikusa, Horino and Mori (1994), who reported that glutamic acid is predominant in rice.

With regard to the split beans, amino acids met the requirement of a diet for children 1 to 3 years of age (INSTITUTE..., 2005), except for the sulfur amino acids (cysteine and methionine) and tryptophan which showed amounts lower than 2.5 and $0.8 \mathrm{mg} .100 \mathrm{mg}^{-1}$ of protein, respectively. The essential and non-essential amino acids profile of split beans (Table 3) is similar to that found by Ribeiro et al. (2007), who studied several common bean cultivars but did not find any cultivar with deficiency of sulfur amino acids due to the fact that the chemical score calculation technique was not applied to indicate limiting amino acids.

The sulfur amino acids (cysteine and methionine), lysine, and tryptophan were limiting in the breakfast cereal showing chemical scores of $0.63,0.77$ and 0.74 , respectively. According to Fonseca Marques and Bora (2000) and Pires et al. (2006), sulfur amino acids are limiting in legumes in general. On the other hand, cereals such as rice have high contents of sulfur amino acids, as verified in this study. However, the amount of rice and beans used was not enough to meet the minimum requirement for children 1-3 years of age, according to the Institute of Medicine (2005); the same was observed for lysine and tryptophan (Table 3). Regarding other essential amino acids, the flake met the minimum requirement for children 1-3 years of age, especially for the amino acids phenylalanine and tyrosine, which together showed a chemical score of 5.53 . Lanfer Marques et al. (1997) found an average of $5.96 \mathrm{mg}$ of phenylalanine. $100 \mathrm{mg}^{-1}$, of recuperated amino acids in a study with 13 brands of flaked cereals. With regard to the non-essential amino acids, the highest amounts found were for glutamic and aspartic.

The dietary fiber content of 3.71 g. $100 \mathrm{~g} \mathrm{~g}^{-1}$ makes this product a source of fiber $\left(>3 \mathrm{~g} .100 \mathrm{~g}^{-1}\right)$, according to the same resolution above. It is important to point out that the high fiber content is a result of the presence of split beans in the mixture. Fiber contents found in this study are similar to those found by Menezes, Caruso and Lajolo (2001) in oat, almonds, and honeybased breakfast cereals, (4.90\%), in "Corn Flakes" (3.57\%), and in wheat and oat $(2.15 \%)$ cereals.

The results in Table 2 indicate loss of thiamine and riboflavin at the final phase of the broken rice and split beans processing;

Table 3. Total proteins (\%) and total amino acid (mg.100 $\mathrm{mg}^{-1}$ of protein) contents in broken rice, split beans, rice and beans breakfast flake, and reference standard (mg.100 $\mathrm{mg}^{-1}$ of protein) (INSTITUTE..., 2005) and chemical score of the breakfast flake $\left(\mathrm{EQ}_{\text {breakfast cereal }}\right)$.

\begin{tabular}{|c|c|c|c|c|c|}
\hline & \multicolumn{5}{|c|}{ Amino acid content } \\
\hline & Broken rice & Split beans & Breakfast cereal & IMA $^{\mathrm{a}}$ & $\mathrm{EQ}_{\text {breakfast cereal }}$ \\
\hline \multicolumn{6}{|l|}{ Essential } \\
\hline Threonine & $2.9 \pm 0.11^{\mathrm{c}}$ & $3.9 \pm 0.04^{\mathrm{a}}$ & $3.3 \pm 0.09^{b}$ & 2.7 & 1.2 \\
\hline Valine & $5.3 \pm 0.12^{\mathrm{a}}$ & $4.8 \pm 0.04^{\mathrm{b}}$ & $4.9 \pm 0.10^{\mathrm{b}}$ & 3.2 & 1.5 \\
\hline Methionine & $2.3 \pm 0.01^{\mathrm{a}}$ & $0.8 \pm 0.03^{c}$ & $1.3 \pm 0.01^{\mathrm{b}}$ & $2.5^{\mathrm{b}}$ & $0.63^{\mathrm{b}}$ \\
\hline${ }^{*} 1 / 2$ Cysteine & $0.60 \pm 0.12^{\mathrm{a}}$ & $0.22 \pm 0.01^{c}$ & $0.30 \pm 0.00^{\mathrm{b}}$ & & \\
\hline Tyrosine & $4.2 \pm 0.24^{\mathrm{a}}$ & $3.4 \pm 0.04^{\mathrm{b}}$ & $3.4 \pm 0.10^{\mathrm{b}}$ & & \\
\hline Phenylalanine & $4.8 \pm 0.02^{\mathrm{b}}$ & $5.6 \pm 0.04^{\mathrm{a}}$ & $4.8 \pm 0.10^{\mathrm{b}}$ & $4.7^{\mathrm{c}}$ & $5.5^{\mathrm{c}}$ \\
\hline Lysine & $2.7 \pm 0.12^{\mathrm{c}}$ & $7.3 \pm 0.09^{a}$ & $3.9 \pm 0.10^{\mathrm{b}}$ & 5.1 & 0.77 \\
\hline Hystidine & $2.0 \pm 0.12^{\mathrm{c}}$ & $3.0 \pm 0.01^{\mathrm{a}}$ & $2.4 \pm 0.10^{\mathrm{b}}$ & 1.8 & 1.3 \\
\hline Tryptophan & $0.18 \pm 0.09^{c}$ & $0.44 \pm 0.04^{\mathrm{b}}$ & $0.59 \pm 0.10^{\mathrm{a}}$ & 0.8 & 0.74 \\
\hline Serine & $4.7 \pm 0.12^{\mathrm{b}}$ & $5.6 \pm 0.04^{\mathrm{a}}$ & $4.6 \pm 0.09^{\mathrm{b}}$ & & \\
\hline Glutamic acid & $17.0 \pm 0.48^{\mathrm{a}}$ & $14.5 \pm 0.02^{\mathrm{b}}$ & $14.4 \pm 0.28^{b}$ & & \\
\hline Proline & $4.3 \pm 0.12^{\mathrm{a}}$ & $3.7 \pm 0.01^{\mathrm{b}}$ & $3.6 \pm 0.09^{b}$ & & \\
\hline Glycine & $4.2 \pm 0.12^{\mathrm{a}}$ & $3.9 \pm 0.01^{b}$ & $3.6 \pm 0.09^{c}$ & & \\
\hline Alanine & $5.4 \pm 0.12^{\mathrm{a}}$ & $4.2 \pm 0.04^{\mathrm{c}}$ & $4.4 \pm 0.09^{\mathrm{b}}$ & & \\
\hline Total protein (\%) & $8.4 \pm 0.22^{c}$ & $22.6 \pm 0.43^{\mathrm{a}}$ & $10.6 \pm 0.18^{b}$ & & \\
\hline
\end{tabular}

Results are in dry basis. Values are means $(n=2) \pm$ standard deviations. The same letters in lines indicate no significant difference between values by Tukey test $(\mathrm{p}<0,05)$. ${ }^{\star} 1 / 2$ Cystine $=1$ cysteine. ${ }^{a}$ Evaluation profile (scoring pattern) for children $1-3$ years old (Institute of Medicine 2005$) .{ }^{\beta}$ methionine + cysteine. ${ }^{c}$ phenylalanine + tyrosine. $\mathrm{EQ}=(\mathrm{mg}$ amino acid.100 mg-1 protein)breakfast flake/ (mg amino acid.100 mg-1 protein)standard protein. 
considering the initial formulation of 70\% broken rice and 30\% split beans, the extruded product recovered $32 \%$ of thiamine and $61 \%$ of riboflavin. Complex B vitamins are very sensitive to heat, light, and $\mathrm{pH}$ changes, and thiamine is less stable during extrusion process. According to Athar et al. (2006), the time and temperature of cooking during extrusion influence the retention of these vitamins. Therefore, it is important to take into account that besides the extrusion process, the flake was sprinkled with a sucrose solution and then dried in oven, which could have caused the degradation of the vitamins.

The portion richest in vitamins is removed from the cereal during processing, and the polished rice is practically absent of vitamins affecting the vitamins content of the final product (ORNELLAS, 1995).

According to the Recommended Daily Intake (RDI) of Proteins, Vitamins, and Minerals (BRASIL, 2005) for nursing and 7-10 years old children, each portion of 100 grams of a breakfast flake (Table 2) would supply $6 \%$ and $4 \%$ of RDI of thiamine and riboflavin, respectively. It is important to notice that the food industry usually adds a mixture of micronutrients (vitamins and minerals) to breakfast cereals to improve the nutritional quality of the product.

The flake processed in this study had a content of $75.71 \mathrm{mg} .100 \mathrm{~g} \mathrm{~g}^{-1}$ of tannins and $165.9 \mathrm{mg} .100 \mathrm{~g}^{-1}$ of phytates. It was observed a reduction of $50.0 \%$ in tannin content in relation to the original content presented in crude matters used for the product formulation, which seems to come mostly from bean flour. This result is lower than that found by Alonso, Aguerre and MARZO (2000), who noticed a decrease of $83 \%$ in tannins of extruded bean sample; however, these authors applied a higher temperature to the extrusion process $\left(152^{\circ} \mathrm{C}-156^{\circ} \mathrm{C}\right)$. Thermal degradation of tannin, as well as changes in their chemical reactivity or formation of insoluble complexes may explain this reduction due to extrusion (BARROGA; LAURENA; MENDOZA, 1985).

On the other hand, the phytate content was kept constant after extrusion, which can be explained by the relative low temperature applied to the process $\left(60^{\circ} \mathrm{C}-80{ }^{\circ} \mathrm{C}\right)$ and the short time the material was in contact with this temperature. According to Deshpande and Damodarn (1990), the phytates are relatively stable to heat, and according to Kon and Sanshuck (1981), the longer the product is under high temperatures, the greater the phytates reduction. Although the extrusion did not reduce the phytate contents, the residual value in the final product $(0.165 \%)$ was lower than that found in cereals such as corn, oat, and wheat (FUKUJI et al. 2008), and also in common beans submitted to other thermal processes (ALONSO; AGUERRE; MARZO, 2000). In addition, it is also important to mention that under low concentrations, this compound has a positive effect on health preventing cancer and cardiovascular diseases, for example (MARTINEZ-DOMINGUEZ; IBAÑEZ; RINCÓN, 2002).

\subsection{Technological characterization of the breakfast cereal}

The results of the technological characterization of the extruded product are in Table 4.
Apparent density is an important physical characteristic of extruded cereals because it interferes directly in the packaging and, consequently, in the cost of the final product. It may vary due to certain parameters such as moisture, extrusion temperature, formulation, and raw material characteristics such as fiber content, protein, and starch (ASCHERI et al., 2005). It is possible to quantify the efficiency of the extrusion process, indirectly, and to evaluate objectively how light or how heavy the extruded products are, as well as to predict its acceptability by the consumer (CARVALHO et al., 2010).

It is important to obtain extruded and expanded breakfast cereals or flaked cereals with high apparent density, low porosity, and thicker walls since those products will be subjected to immersion in an aqueous medium like milk, for example, and keep their texture for as long as possible with low rate of water absorption (MERCIER; LINKO; HARPER, 1998).

The flake obtained in this study had an apparent density of $0.25 \mathrm{~g} . \mathrm{cm}^{-3}$, a value close to those found by Ascheri et al. (2005) when working with expanded products from raw amaranthus flour and broken rice. They reported values varying from 8.13 to $8.68{\mathrm{~g} . \mathrm{cm}^{-3}}^{3}$ and by Oliveira (2007) who reported values from 0.18 to 0.92 g.cm ${ }^{-3}$ for expanded and extruded soybean seed coat and corn products.

The expansion index is an indicator that allows predicting how drastic or how light was the extrusion process at a first look (LUSAS; RIAZ, 1994). Chiang and Johnson (1977) stated that it is related to the degree of gelatinization and water evaporation when the product leaves the matrix.

The breakfast flake containing rice and beans showed an expansion index of 8.89, higher than that found by Vernaza, Chang and Steel (2009) in breakfast cereals containing passiflora meal and corn flour (1.02 to 4.11), Camargo, Leonel and Mischan (2008), working with extruded cookies based on sour tapioca flour and fiber (3.5 to 5.7), and by Leonel, Martins and Mischan (2010) working with sweet tapioca flour and orange fiber (1.93 to 2.99). The high values obtained in this study evidence the high starch content of rice extrudes, and that their maximum degree of expansion is closely related to starch content and degree of purity.

Texture is critical for the quality of crunchy and expanded products. It can be described by the compressive deformation of solids subjected to high pressure. The mechanical properties of food subjected to high compression ratio are related to the sensory properties of crunchiness since chewing encompasses high deformation ratio (MERCIER; LINKO; HARPER, 1998). Hardness and crunchiness are consumers perception associated with expansion and with the structure of the extruded cells (DING et al., 2005).

Table 4. Results of apparent density, expansion index, and instrumental texture (means and standard deviation) for the breakfast flake containing rice and beans ${ }^{*}$

\begin{tabular}{ccc}
\hline Apparent density $\left(\mathrm{g} . \mathrm{cm}^{-3}\right)$ & Expansion index & Texture (g.f) \\
\hline $0.25 \pm 0.00$ & $8.89 \pm 0.14$ & $1087.44 \pm 220.44$ \\
\hline *Values are means $(\mathrm{n}=3) \pm$ standard deviations.
\end{tabular}

*Values are means $(n=3) \pm$ standard deviations. 


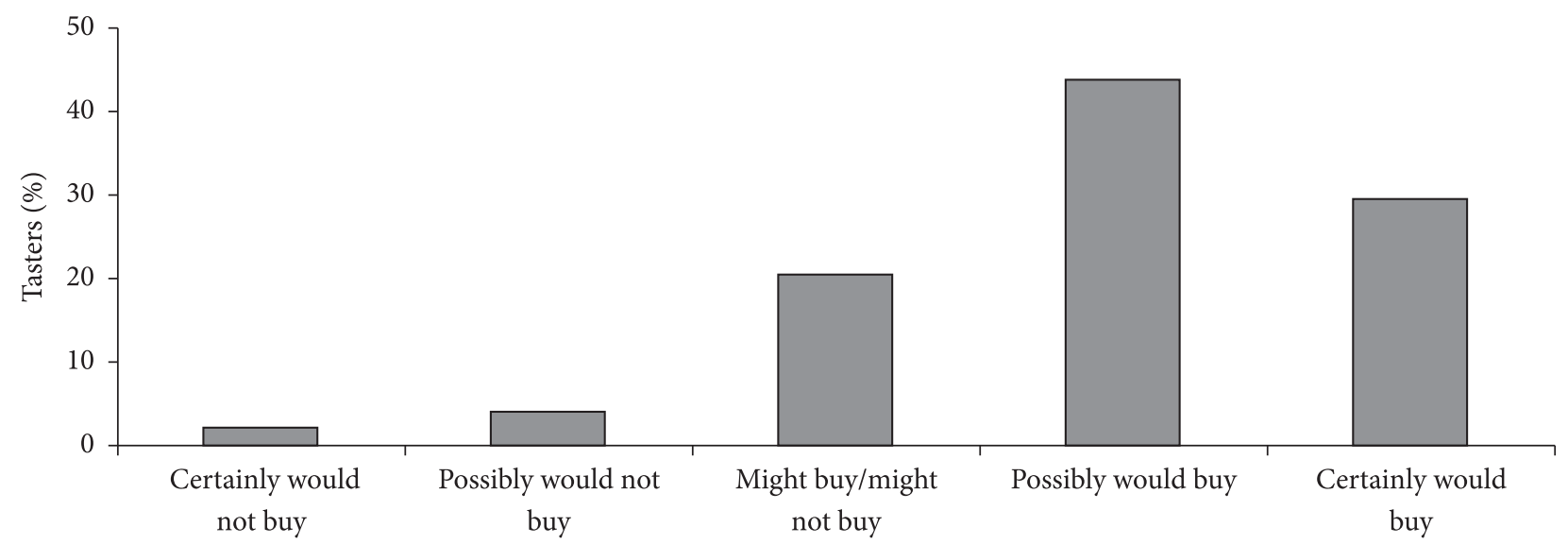

Figure 2. Percent distribution of the purchase intention of the breakfast cereal containing broken rice and split beans.

Table 5. Sensory acceptability and purchase intention of the breakfast cereal.

\begin{tabular}{lcc}
\hline \multicolumn{1}{c}{ Attributes } & Means \pm standard deviation* & \% of acceptance \\
\hline Colour & $6.8 \pm 1.30$ & 75.5 \\
Flavour & $7.2 \pm 1.37$ & 80.2 \\
Texture & $7.7 \pm 1.16$ & 85.2 \\
Overall impression & $7.3 \pm 1.20$ & 81.3 \\
Purchase intention & $3.9 \pm 0.92$ & 79.0 \\
\hline
\end{tabular}

*Values are means $(\mathrm{n}=100) \pm$ standard deviations.

In breakfast cereals or flakes, a more compact structure is desirable to avoid fast water absorption when immersed in milk. This product showed hardness of 1087.44 g.f, similar to that verified by Alves and Grossmann (2002) in yam flour snacks, from 757.43 g.f to 1210.7 g.f. Vernaza, Chang and Steel (2009), studying various conditions of the extrusion process in the elaboration of passion fruit meal and corn flour breakfast cereal, reported a wide range of hardness, varying from 954 g.f to $2623.73 \mathrm{~g}$.f, with the lowest values close to those of the rice and beans breakfast cereal, verified under lower moisture and smaller dietary fiber content conditions. Mercier, Linko and Harper (1998) stated that fibers usually reduce the product expansion due to the rupture of the cell walls before gas bubbles expand up to the maximum size, resulting in hard, compact, not crunchy, and undesired sensory texture.

On the other hand Lustosa, Leonel and Mischan (2010) found hardness values varying from 4430 g.f to 12320 g.f in snacks of cassava flour; but Leonel, Martins and Mischan (2010) found values from $3580 \mathrm{~g}$.f to $5900 \mathrm{~g}$.f in snacks of soybean flour and sour tapioca flour; values significantly higher than those found in this study.

\subsection{Sensory analysis}

The means of the acceptability test and purchase intention of the breakfast cereal are shown in Table 5.

One of the most important attributes of breakfast cereals or flakes is crunchiness. It is associated with freshness and quality, and its absence is one of the reasons for consumer rejection. The product had $81.3 \%$ of acceptance; a very high index, considered satisfactory.
The histogram with the percent distribution of purchase intention of the breakfast cereal elaborated with broken rice and split beans is shown in Figure 2.

As seen in Figure 2, the majority of the panelists, 73\%, gave scores 4 or 5; in other words, "possibly" or "certainly" would purchase the product confirming the good acceptability of the extruded breakfast cereal. Low level of rejection was also observed. Only two panelists out of 100 reported that they "certainly" would not buy it.

\section{Conclusions}

It is possible to produce an extruded breakfast cereal mixing broken rice flour with split bean flour in a 70:30 ratio. The final product had a significant content of proteins, allowing its classification as a source of proteins for adults. With regard to fiber content, the cereal may be claimed as food source of dietary fiber, according to the Brazilian legislation.

The sensory analysis indicated good acceptability with an acceptance index of $81.3 \%$ for overall impression, and $73 \%$ of the panelists reported that they "possibly" would purchase the product if available in the market.

Broken rice and split beans are alternatives for the elaboration of extruded breakfast flakes, and those prepared in the ratio of 70:30 (rice:beans) showed good sensory, technological, and nutritional characteristics.

\section{References}

ALONSO, R.; AGUERRE, A.; MARZO, F. Effects of extrusion and tradicional processing methods on antinutrients and in vitro digestibility of protein and starch in faba and kidney beans. Food Chemistry, v. 68, 2000, p. 159-165. http://dx.doi.org/10.1016/ S0308-8146(99)00169-7

ALVAREZ-MARTINEZ, L.; KONDURY, K. P.; HARPER, J. M. A general-model for expansion of extruded products. Journal of Food Science, v. 53, n. 2, p. 609-615, 1988. http://dx.doi. org/10.1111/j.1365-2621.1988.tb07768.x

ALVES, R. M. L.; GROSSMANN, M. V. E. Parâmetros de extrusão para produção de "snacks" de farinha de cará (Dioscorea alata). Ciência e Tecnologia de Alimentos, v. 22, n. 1, p. 32-38, 2002. 
ANTUNES, P. L. et al. Valor nutricional de feijão (Phaseolus vulgaris L), cultivares Rico 23, Carioca, Piratã-1 e Rosinha G-2. Revista Brasileira de Agrociência, v. 1, n. 1, p. 12-18, 1995.

ASSOCIATION OF OFFICIAL ANALYTICAL CHEMISTS - AOAC. Official methods of analysis of the Association of Official Analytical Chemists. 16th ed. Washington: AOC, 1997.

ASCHERI, J. L. R.; CARVALHO, C. W. P. Efecto de los parámetros de extrusion, características de pasta y textura de pellets (snacks de terceira generación) producidos a partir de trigo y maiz. Alimentaria, v. 35, n. 279, p. 93-98, 1997.

ASCHERI, J. L. R. et al. Efecto de la formulación sobre la expansión y viscosidad de snacks (pellets) producidos por extrusión termoplástica. Alimentaria, v. 268, n. 12, p. 111-118, 1995.

ASCHERI, J. L. R. et al. Extrusión de harina mixta de amaranto integral y arroz: Parte I. Caracterización físico-química. Alimentaria, v. 42, n. 367, p. 74-83, 2005.

ATHAR, N. et al. Vitamin retention in extruded food products. Journal of Food Composition and Analysis, v. 19, n. 4, p. 379-383, 2006. http://dx.doi.org/10.1016/j.jfca.2005.03.004

BARROGA, C. F.; LAURENA, A. C.; MENDOZA, M. T. Polyphenols in mung bean (Vigna radiata L., Wilczek): determination and removal. Journal of Agricultural and Food Chemistry, v. 33, p. 1006-1009, 1985. http://dx.doi.org/10.1021/jf00065a056

BASSINELLO, P. Z. et al. Characterization of cookies formulated with rice and black bean extruded flours. Procedia Food Science, v. 1, p. 1645-1652, 2011. http://dx.doi.org/10.1016/j.profoo.2011.09.243

BRASIL. Resolução RDC no 269, de 22 setembro de 2005. Agência Nacional de Vigilância Sanitária adota o regulamento técnico sobre a Ingestão Diária Recomendada (IDR) de proteínas, vitaminas e minerais e dá outras providências. Diário Oficial da República Federativa do Brasil, Brasília, DF, 23 set. 2005. Seção 1, n. 184, p. 372.

BRASIL. Resolução RDC no 359, de 23 de dezembro de 2003. Agência Nacional de Vigilância Sanitária aprova o regulamento técnico de porções de alimentos embalados para fins de rotulagem nutricional. Diário Oficial da República Federativa do Brasil, Brasília, DF, 26 dez. 2003. Seção 1, n. 251, p. 28-32.

CAMARGO, K. F.; LEONEL, M.; MISCHAN, M. M. Produção de biscoitos extrusados de polvilho azedo com fibras: efeito de parâmetros operacionais sobre as propriedades físicas. Ciência e Tecnologia de Alimentos, v. 28, n. 3, p. 586-591, 2008. http://dx.doi. org/10.1590/S0101-20612008000300013

CARVALHO, A. V. et al. Caracterização tecnológica de extrusados de terceira geração à base de farinhas de mandioca e pupunha. Ciencia e Agrotecnologia, v. 34, n. 4, p. 995-1003, 2010. http:// dx.doi.org/10.1590/S1413-70542010000400028

CARVALHO, R. V.; ASCHERI, J. R. A.; CAL-VIDAL, J. Efeito dos parâmetros de extrusão nas propriedades físicas de pellets ( $3 \mathrm{~g})$ de misturas de farinhas de trigo, arroz e banana. Ciência e Agrotecnologia, v. 26, n. 5, p. 1006-1018, 2002.

CHIANG, B. Y.; JOHNSON, J. A. Gelatinization of the starch in extruded products. Cereal Chemistry, v. 54, n. 3, p. 436-443, 1977.

CLERICI, M. T. P. S.; EL-DASH, A. A. Características tecnológicas de farinhas de arroz pré-gelatinizadas obtidas por extrusão termoplástica. Ciência e Agrotecnologia, v. 32, n. 5, p. 1543-1550, 2008. http:// dx.doi.org/10.1590/S1413-70542008000500028

DESHPANDE, S. S.; DAMODARAN, S. Food legumes: chemistry and technology. Advances in Cereal Science and Technology, v. 10, p. 147-241, 1990.
DING, Q. et al. The effect of extrusion conditions on the physicochemical properties and sensory characteristics of rice-based expanded snacks. Journal of Food Engineering, v. 66, n. 3, p. 283-289, 2005. http://dx.doi.org/10.1016/j.jfoodeng.2004.03.019

DORS, G. C.; CASTIGLIONI, G. L.; RUIZ, W. A. Utilização da farinha de arroz na elaboração de sobremesa. Vetor, v. 16, n. 1-2, p. 63-67, 2006.

EUROPEAN COMMITTEE FOR STANDARDIZATION. European Standard EN 14152: 2003-09. Lebensmittel - Bestimmung von Vitamin B1 mit HPLC. Foodstuffs: Determination of vitamin B1 by HPLC, English version of DIN EN 14122. Berlin, 2003a.

EUROPEAN COMMITTEE FOR STANDARDIZATION. European Standard EN 14152: 2003-10. Lebensmittel - Bestimmung von Vitamin B2 mit HPLC. Foodstuffs: Determination of vitamin B2 by HPLC, English version of DIN EN 14152. Berlin, 2003b.

FERREIRA, C. M.; DEL PELOSO, M. J.; FARIA, L. C. Feijão na economia nacional. Santo Antônio de Goiás: Embrapa Arroz e Feijão, 2002. 47 p. (Embrapa Arroz e Feijão. Documentos, n. 135). Disponível em: <http://docsagencia.cnptia.embrapa.br/feijao/ doc_135.pdf $>$. Acesso em: 09 fev 2012.

FONSECA MARQUES, M. F., BORA, P. S. Composicíon química y análisis de aminoácidos de alubias. Ciencia e Tecnología Alimentaria, v. 2, n. 5, p. 248-252, 2000.

FUKUJI, T. S. et al. Ácido fítico em híbridos de milho e alguns produtos industrializados. Acta Scientiarum Agronomia, v. 30, p. 31-35, 2008.

GONZÁLEZ, J. R.; TORRES, R. L.; DE GREEF, D. M. Extrusión-cocción de cereales. Boletim da SBCTA, v. 36, n. 2, p. 104-115, 2002.

GUY, R. Extrusión de los alimentos. Zaragoza: Acribia, 2001. 208 p.

HAUG, W.; LANTZSCH, H. Sensitive method for the rapid determination of phytate in cereals and cereal products. Journal of the Science of Food and Agriculture, v. 34, n. 12, p. 1423-1426, 1983. http://dx.doi.org/10.1002/jsfa.2740341217

INSTITUTO BRASILEIRO DE GEOGRAFIA E ESTATÍSTICA - IBGE. Aquisição alimentar domiciliar per capita: Brasil e grandes regiões. Pesquisa de Orçamentos Familiares 2008-2009. Rio de Janeiro, 2010a. Disponível em: <http://www.ibge.gov.br/home/ estatistica/populacao/condicaodevida/pof/2008_2009_aquisicao/ pof20082009_aquisicao.pdf>. Acesso em: 13 fev. 2012.

INSTITUTO BRASILEIRO DE GEOGRAFIA E ESTATÍSTICA - IBGE. Avaliação nutricional da disponibilidade domiciliar de alimentos no Brasil. Pesquisa de Orçamentos Familiares 2008-2009. Rio de Janeiro, 2010b. Disponível em: <http://www.ibge.gov.br/home/ estatistica/populacao/condicaodevida/pof/2008_2009_aval_ nutricional/pof20082009_avaliacao.pdf>. Acesso em: 13 fev. 2012.

INSTITUTE OF MEDICINE. Dietary reference intakes for energy, carbohydrate, fiber, fat, fatty acids, cholesterol, protein, and amino acids (macronutrients). Washington: The National Academies Press, 2005. p. 589-768.

JONES, J. M. The benefits of eating breakfast cereals. Cereal Foods World, v. 46, n. 10, p. 461-467, 2001.

JULIANO, B. O. Rice in human nutrition. Rome: FAO, 1983. 166 p.

KON, S.; SANSHUCK, D. W. Phytate content and its effect on cooking quality of beans. Journal of Food Processing and Preservation, v. 5, p. 169-178, 1981. http://dx.doi.org/10.1111/j.1745-4549.1981. tb00632.x

LABUZA, T. P. The effect of water activity on kinectics of food deterioration. Food Technology, v. 39, n. 4, p. 36-41, 1980. 
LANFER MARQUEZ, U. M. et al. Estudo da composição química de flocos de cereais com ênfase nos teores de fenilalanina. Ciência e Tecnologia de Alimentos, v. 17, n. 3, p. 314-319, 1997.

LEONEL, M.; MARTINS, J. C.; MISCHAN, M. M. Produção de snacks funcionais à base de farinha de soja e polvilho azedo. Ciência Rural, v. 40, n. 6, p. 1418-1423, 2010. http://dx.doi.org/10.1590/ S0103-84782010005000092

LIMBERGER, V. M. et al. Produção de salgadinho extrusado de quirera de arroz para uso na indústria de alimentos. Ciência Rural, v. 39, n. 9, p. 2590-2594, 2009. http://dx.doi.org/10.1590/S010384782009000900032

LUSAS, E.; RIAZ, M. An introduction to extruders and extrusion principles. Extrusion Communiqué, v. 7, n. 4, p. 9-34, 1994.

LUSTOSA, B. H. B.; LEONEL, M.; MISCHAN, M. M. Parâmetros de extrusão na produção de snacks de farinha de mandioca enriquecidos com caseína. Ciências Agrárias, v. 31, n. 1, p. 109-126, 2010.

MARTINEZ-DOMINGUEZ, B.; IBAÑEZ, M. B.; RINCÓN, F. Acido fítico: aspectos nutricionales e implicaciones analíticas. Archivos Latinoamericanos Nutricion, v. 52, n. 3, p. 219-231, 2002. Pmid:12448335.

MECHI, R.; BRAZACA, S. G. C.; ARTHUR, V. Avaliação química, nutricional e fatores antinutricionais do feijão preto (Phaseolus vulgaris L.) irradiado. Ciência e Tecnologia de Alimentos, v. 25 , n. 2, p. 109-114, 2005. http://dx.doi.org/10.1590/S010120612005000100018

MENEZES, E. W.; CARUSO, L.; LAJOLO, F. M. Avaliação da qualidade dos dados de fibra alimentar. Estudo em alimentos brasileiros. In: LAJOLO, F. M. et al. (Ed.). Fibra dietética en Iberoamerica: tecnología y salud. 2. ed. São Paulo: Varela, 2001. p. 165-178.

MENEZES, H. C.; SOUZA, M. L. Avaliação sensorial de cereais matinais de castanha-do-brasil com mandioca extrusados. Ciência e Tecnologia de Alimentos, v. 26, n. 4, p. 950-955, 2006. http:// dx.doi.org/10.1590/S0101-20612006000400036

MENDONÇA, X. M. F. D.; ASCHERI, J. L., ASCHERI, D. P. R. Efecto de la adición de aislado protéico de soya en las propiedades físico-químicas de pellets de harina de arroz. Alimentaria, v. 38, n. 319, p. 53-62, 2001.

MERCIER, C.; LINKO, P.; HARPER, J. M. Extrusion cooking. 2nd ed. St. Paul: American Association of Cereal Chemists, 1998. 199 p.

MOHAMED, S. Factors affecting extrusion characteristics of expanded starch-based products. Journal of Food Processing and Preservation, v. 14, n. 6, p. 437-452, 1990. http://dx.doi. org/10.1111/j.1745-4549.1990.tb00145.x

OLIVEIRA, G. D. Obtenção de produtos extrusados expandidos e não-expandidos de casca de soja e milho. 2007. $104 \mathrm{f}$. Dissertação (Mestrado em Ciência e Tecnologia de Alimentos)- Universidade Federal do Rio de Janeiro, Rio de Janeiro, 2007.

ORNELLAS, L. H. Técnica dietética: seleção e preparo dos alimentos. 6. ed. São Paulo: Atheneu, 1995. p. 191-194.

PIRES, C. V. et al. Qualidade nutricional e escore químico de aminoácidos de diferentes fontes protéicas. Ciência e Tecnologia de Alimentos, v. 26, n. 1, p. 179-187, 2006. http://dx.doi.org/10.1590/ S0101-20612006000100029

PRESOTO, A. E. F.; ALMEIDA-MURADIAN, L. B. Validação de métodos cromatográficos por CLAE para análises das vitaminas B1, B2, B6 e niacina naturalmente presentes em farinhas de cereais. Química Nova, v. 31, n. 3, p. 498-502, 2008. http://dx.doi. org/10.1590/S0100-40422008000300006
RAMÍREZ-CÁRDENAS, L.; LEONEL, A. J.; COSTA, N. M. B. Efeito do processamento doméstico sobre o teor de nutrientes e de fatores antinutricionais de diferentes cultivares de feijão comum. Ciência e Tecnologia de Alimentos, v. 28, n. 1, p. 200-213, 2008.

RIAZ, M. N. Extruders in food applications. Boca Raton: CRC Press, 2000. $225 \mathrm{p}$.

RIBEIRO, N. D. et al. Composição de aminoácidos de cultivares de feijão e aplicações para o melhoramento genético. Pesquisa Agropecuária Brasileira, v. 42, n. 10, p. 1393-1399, 2007. http:// dx.doi.org/10.1590/S0100-204X2007001000004

ROCHA-GUZMAN, N. E. et al. Physical Properties of Extruded Products from Three Mexican Common Beans (Phaseolus vulgaris L.) Cultivars. Plant Foods Human Nutrition, v. 63, p. 99-104, 2008. PMid:18546074. http://dx.doi.org/10.1007/s11130-008-0076-x

SAIKUSA, T.; HORINO, T.; MORI, Y. Distribution of free amino acids in the rice kernel fractions and the effect of water soaking on the distribution. Journal of Agricultural and Food Chemistry, v. 42, n. 5, p. 1122-1125, 1994. http://dx.doi.org/10.1021/jf00041a015

SILVA, R. F.; ASCHERI, J. L. R. Extrusão de quirera de arroz para uso como ingrediente alimentar. Brazilian Journal of Food Technology, v. 12, n. 3, p. 190-199, 2009. http://dx.doi.org/10.4260/ bjft2009800900012

SILVA, P. A. et al. Desenvolvimento e caracterização de cereal matinal extrudado de mandioca enriquecido com concentrado proteico de soro de leite. Brazilian Journal of Food Technology, v. 14, n. 4, p. 260-266, 2011. http://dx.doi.org/10.4260/BJFT2011140400031

SILVA, A. G.; ROCHA, L. C.; CANNIATI BRAZACA, S. G. Caracterização físico-química, digestibilidade protéica e atividade antioxidante de feijão comum (Phaseolus vulgaris L.). Alimentos e Nutrição, v. 20, n. 4, p. 591-598, 2009.

STATSOFT. Statistics for windows. Version 5.0. Tulsa, 1995.

STONE, H. S.; SIDEL, J. L. Sensory evaluation practices. 2nd ed. San Diego: Academic Press, 1993. 338 p.

STRAHM, B. Fundamentals of polymer science as an applied extrusion tool. Cereal Foods World, v. 43, n. 8, p. 621-625, 1998.

TAKEUCHI, K. P.; CUNHA, R. L.; SABDINI, E. Análise das propriedades mecânicas de cereais matinais com diferentes fontes de amido durante o processo de absorção de leite. Ciência e Tecnologia de Alimentos, v. 25, n. 1, p. 78-85, 2005. http://dx.doi.org/10.1590/ S0101-20612005000100013

TEBA, C. S.; ASCHERI, J. L. R.; CARVALHO, C. V. P. Efeito dos parâmetros de extrusão sobre as propriedades de pasta de massas alimentícias pré-cozidas de arroz e feijão. Alimentos e Nutrição, v. 20, n. 3, p. 411-426, 2009.

TEDRUS, G. A. S. et al. Estudo da adição de vital glúten à farinha de arroz, farinha de aveia e amido de trigo na qualidade de pães. Ciência e Tecnologia de Alimentos, v. 21, n. 1, p. 20-25, 2001. http://dx.doi.org/10.1590/S0101-20612001000100006

THE NIELSEN COMPANY. Cereais matinais: desafios e oportunidades. São Paulo, 2008. Disponível em: <http://br.nielsen.com/news/ cereais2008.shtml>. Acesso em: 09 fev. 2012.

UNITED STATES DEPARTMENT OF AGRICULTURE - USDA. Agricultural Research Center Service Composition of foods. Washington, 1963. (Agriculture Handbook, n. 8).

UNIVERSIDADE ESTADUAL DE CAMPINAS - UNICAMP. Tabela brasileira de composição de alimentos - TACO. Versão 2. 2. ed. Campinas: UNICAMP/NEPA, 2006. 113 p. Disponível em: <http://www.unicamp.br/nepa/taco/>. Acesso em: 20 out. 2010 . 
VERNAZA, M. G.; CHANG, Y. K.; STEEL, C. J. Efeito do teor de farelo de maracujá e da umidade e temperatura de extrusão no desenvolvimento de cereal matinal funcional orgânico. Brazilian Journal of Food Technology, v. 12, n. 2, p. 145-154, 2009. http:// dx.doi.org/10.4260/BJFT2009800900007

WAlter, M.; MARCheZAN, E.; ÁVIlA, L. A. Arroz: composição e características nutricionais. Ciência Rural, v. 38, n. 4, p. 1184-1192, 2008. http://dx.doi.org/10.1590/S010384782008000400049

WHITE, J. A.; HART, R. J.; KRY, J. C. An evaluation of the waters picotag system for the amino acid analysis of food materials. Journal of Automatic Chemistry, v. 8, n. 4, p. 170-177, 1986. PMid:18925132 PMCid:2547673. http://dx.doi.org/10.1155/S1463924686000330 